\title{
PENINGKATAN KETAHANAN TANAMAN PISANG BARANGAN TERHADAP BLOOD DISEASE BACTERIUM (BDB) DENGAN APLIKASI FUNGI MIKORIZA ARBUSKULAR INDIGENUS
}

\author{
Suswati $^{1}$, Nasir $\mathbf{N}^{2}, \&$ Azwana ${ }^{1}$ \\ ${ }^{1}$ Program Studi Agroteknologi Fakultas Pertanian,Universitas Medan Area. 20223 \\ ${ }^{2}$ Program Studi Biologi Pascasarjana Universitas Andalas, Kampus Unand Limau Manis. 25163 \\ E-mail: suswatifebri@gmail.com
}

\begin{abstract}
Increase resistence of barangan banana blood disease bacterium using Indigenus arbuscular mycorhizae fungi. Blood disease caused by Blood disease bacterium (BDB) is the major cause of production loss of banana in Indonesia. There is currently a lack of information about the application of indigenous Arbuscular mycorrhizal fungi (AMF) to increase the Barangan banana resistance to BDB. A greenhouse experiment was conducted to evaluate the increase resistance Barangan banana to 3 (three) types of AMF (Glomus type-1; Acaulospora type-4 and Glomus fasciculatum) and control (without AMF) with 3 replicates. Barangan banana plantlet were inoculated with $50 \mathrm{~g}$ fresh AMF inoculants and at 14 days after acclimating have transplanted to soil contaminated BDB. Observation on the Barangan banana seedlings was done after 5-60 days after application included percentage disease, severity disease, incubation periode, BDB population in rhizosfer and AMF percentage root colonization. The result indicated that AMF increased Barangan banana resistance to BDB. Glomus type-1 and G. fasciculatum increased banana resistance by $100 \%$ while Acaulospora type- 4 takes $66.67 \%$ and control none. The disease severity with Acaulospora tipe-4 is $6 \%$ lower than controls (32.6\%). The highest suppression level was found in 2 isolates of Glomus application was $100 \%$ and was followed Acaulospora type-4 is $81.59 \%$. The low intensity of on FMA indigenous treatment applications related to the incubation period and BDB density in rhizosphere of plant roots. The incubation period in mychorized plants has longer 30 dap than controls (10 dap).
\end{abstract}

Key words: blood disease bacterium, banana seedling, arbuscular mycorrhizal fungi, plant resistance, Barangan banana.

\section{ABSTRACT}

Peningkatan ketahanan tanaman pisang barangan terhadap blood disease bacterium (BDB) dengan aplikasi fungi mikoriza arbuskular indigenus. Penyakit darah (Blood disease bacteria) yang disebabkan oleh BDB merupakan penyebab utama kehilangan hasil pisang di Indonesia. Tujuan penelitian memperoleh data efektifitas peningkatan ketahanan tanaman bibit Barangan terhadap BDB. Penelitian ini menggunakan Rancangan Acak Lengkap dengan perlakuan 3 jenis FMA ( Glomus tipe 1; Acaulospora tipe 4) dan Glomus fasciculatum). Sumber inokulan FMA segar diperoleh dari perbanyakan masingmasing jenis FMA berupa media tanam pasir yang mengandung spora, potongan akar terkolonisasi dan hifa. Plantlet Barangan diaplikasi dengan $50 \mathrm{~g}$ inokulan FMA. Pada umur $14 \mathrm{hsa}$ (hari setelah aklimatisasi) bibit dipindah pada polybag yang berisi media tanam yang terkontaminasi BDB, pengamatan perkembangan gejala penyakit dilakukan pada 5-60 hari setelah pindah (hsp). Parameter yang diamati : persentase, intensitas serangan, kepadatan BDB, masa inkubasi kemudian dihitung efektivitas peningkatan ketahanan bibit Barangan. Hasil yang diperoleh adalah FMA dapat menginduksi ketahanan tanaman pisang Barangan terhadap BDB. Kemampuan Glomus type-1 and G.fasciculatum lebih tinggi dalam meningkatkan ketahanan tanaman pisang Barangan dibanding Acaulospora tipe-4. Intensitas serangan BDB dengan aplikasi Acaulospora tipe-4 yaitu $6 \%$ lebih rendah dibanding kontrol (32,6\%). Efektifitas penekanan intensitas serangan tertinggi ditemukan pada perlakuan aplikasi 2 isolat Glomus yaitu 100\% dan diikuti Acaulospora tipe-4 81,59\%. Rendahnya intensitas serangan pada perlakuan aplikasi FMA indigen berkaitan dengan masa inkubasi dan kepadatan BDB di rizosfir perakaran tanaman. Pada tanaman pisang bermikoriza masa inkubasi BDB menjadi lebih panjang yaitu $30 \mathrm{hst}$ sementara kontrol (10 hst)

Kata kunci: Blood disease bacteria, fungi mikoriza arbuskular, ketahanan tanaman, plantlet, bibit pisang Barangan 


\section{PENDAHULUAN}

Pisang Barangan merupakan pisang unggul yang memiliki rasa, tekstur dan warna yang sangat disukai oleh penggemar pisang meja di Sumatera Utara. Jenis pisang ini merupakan komoditas penting yang sangat mendukung ekonomi dan aktifitas budaya di Sumatera Utara. Namun semenjak tahun 1990an, pertanaman pisang di Sumatera Utara rusak berat akibat penyakit layu bakteri yang disebabkan oleh BDB. Patogen ini merupakan penyakit utama pisang Barangan (Sulyo, 1992) karena mampu menyerang semua stadia pertumbuhan tanaman pisang (bibit, tanaman dewasa ataupun tanaman yang telah membentuk tandan) (Wardlaw, 1972) dan bersifat mematikan dengan menginfeksi jaringan pembuluh tanaman secara sistemik (Eden-Green, 1992).

Pengendalian penyakit darah sulit dilakukan karena propagul infektif BDB dapat bertahan hingga 12 tahun dalam tanah dan jaringan tanaman terserang tanpa kehilangan virulensinya. Tingginya propagul infektif BDB di dalam tanah mengakibatkan tidak produktifnya lahan-lahan endemik pertanaman pisang. Berbagai cara pengendalian telah dilakukan seperti menekan sumber inokulum awal dengan menggunakan bibit tanaman sehat, tidak menanam tanaman inang lainnya yaitu jenis pisang hias (Heliconia sp.), sanitasi kebun dan pembuatan saluran drainase, menjarangkan anakan, pengapuran, menghindari terjadinya pelukaan akar saat pemeliharaan tanaman, pengerodongan bunga dan buah dengan plastik, memotong bunga jantan (jantung pisang) segera setelah sisir buah terakhir terbentuk, pemusnahan tanaman terserang dengan cara membongkar tanaman dan membakarnya atau dengan menyuntikkan minyak tanah pada batang semu tanaman terserang (10-20 ml tanaman $\left.^{-1}\right)$. Berbagai cara tersebut belum mampu mengendalikan patogen penyakit darah bakteri. Sampai saat ini belum ada metode pengendalian patogen ini yang berhasil secara ekonomis (Buddenhagen \& Elasser, 1962; Ploetz, 1990).

Salah satu alternatif pengendalian yang mempunyai harapan untuk dikembangkan adalah penggunaan agensia hayati fungi mikoriza arbuskula (FMA). Aplikasi mikoriza pada saat aklimatisasi plantlet pisang sangat diperlukan (Declerck et al., 1995). Hal ini disebabkan karena tanaman pisang hasil perbanyakan secara kultur jaringan memiliki tingkat ketergantungan yang tinggi terhadap FMA. Disamping itu tanaman pisang memiliki akar serabut dan sistem perakaran yang dangkal, sehingga sangat rentan terhadap cekaman air (kekurangan dan kelebihan air) (Subakti dan Supriyanto, 1996).
Pemanfaatan FMA sebagai agen penginduksi ketahanan berbagai jenis pisang telah dilakukan. Efek induksi ketahanan tanaman pisang dapat dilihat dari berbagai indikator diantaranya indikator fitopatologi dan agronomi. Indikator fitopatologi seperti: rendahnya persentase, intensitas serangan $\mathrm{BDB}$, rendahnya kepadatan propagul bakteri di dalam jaringan tanaman dan indikator agronomi yaitu terjadinya peningkatan pertumbuhan tanaman (tinggi tanaman, jumlah daun dan berat tanaman) dan peningkatan kolonisasi FMA.

Berdasarkan penelitian yang telah dilakukan pada tanaman pisang Kepok, aplikasi FMA indigenus (Glomus tipe-1 dan Acaulospora tipe-4) yang berasal dari rizosfer tanaman pisang Kepok di lahan endemik penyakit darah bakteri, Kecamatan Baso, Kabupaten Agam, Sumatera Barat dapat menginduksi tanaman pisang Kepok terhadap BDB dalam pengujian rumah kaca (Suswati et al., 2007). Kedua jenis FMA indigenus tersebut juga dapat mempercepat masa berbuah dan meningkatkan $25-30 \%$ produksi di lahan endemik dan mampu menurunkan persentase dan intensitas serangan hingga 90,8\% (Suswati et al., 2011b). Dalam penelitian Maharadingga et al. (2009), isolat FMA tersebut mampu menekan perkembangan penyakit Fusarium oxysporum f sp. cubense (Foc), meningkatkan ketahanan semaian cabai merah terhadap Sclerotium roolfsii, memperpanjang masa inkubasi BDB pada pisang Cavendish (Yefriwati et al., 2005). Aplikasi FMA pada saat aklimatisasi dapat meningkatkan pertumbuhan mikropropagasi pantlet pisang, pisang Cavendish (Musa acuminata Colla AAA) (Ariningsih, 2009) menyebabkan perbaikan pertumbuhan vegetatif yang lebih baik di tanah masam. Aplikasi in vitro Glomus intraradices dapat meningkatkan pertumbuhan dan ketersediaan $\mathrm{P}$ terhadap mikropropagasi pisang (Musa spp. cv. Grand Naine) (Declerck et al., 2000). Menurut Suharti et al. (2012) aplikasi FMA indigenus dari rizosfer tanaman jahe dapat meningkatkan ketahanan jahe terhadap $R$. solanacearum ras 4.

Induksi ketahanan tanaman yang rentan merupakan salah satu mekanisme pengendalian hayati yang sangat potensial untuk dikembangkan karena penggunaannya lebih praktis (diaplikasi pada benih/bibit), efisien (tidak perlu berulang-ulang), ekonomis dan ramah lingkungan (Habazar, 2004). Efek induksi ketahanan dapat dilihat dari beberapa parameter fitopatologi seperti: tidak terserangnya tanaman, rendahnya intensitas serangan dan terhambatnya pertumbuhan bakteri BDB di dalam jaringan akar tanaman pisang Barangan.

Penelitian ini bertujuan untuk mengetahui tingkat efektifitas kemampuan induksi isolat FMA indigen 
terhadap penyakit darah bakteri pada tanaman pisang Barangan.

\section{METODE PENELITIAN}

Penelitian ini dilaksanakan di rumah kawat dan Laboratorium Program Studi Agroteknologi, Fakultas Pertanian, Universitas Medan Area dimulai dari Maret sampai dengan Juli 2012.

Persiapan Plantlet Pisang Barangan, Aplikasi FMA dan Penanaman Bibit Pisang. Pada penelitian ini digunakan 3 isolat Fungi mikoriza arbuskular (FMA) yaitu: Glomus tipe-1 dan Acaulospora tipe-4 dan Glomus fasciculatum (isolat FMA dari rizosfir tanaman karet, koleksi Prof. Dr. Ir. Eti Farda Husin, M.S). Perlakuan adalah aplikasi isolat FMA indigenus (A) pada plantlet pisang sebagai berikut: $\mathrm{A} 0=$ kontrol (tanpa FMA), A1 = Glomus tipe-1, A2 = Acaulospora tipe-4, $\mathrm{A} 3=$ G. fasciculatum (isolat pembanding), setiap perlakuan diulang 5 kali.

Planlet pisang yang digunakan adalah kultivar Barangan hasil perbanyakan in-vitro yang berasal dari perusahaan swasta kultur jaringan, Medan. Plantlet pisang dikeluarkan dari dalam botol, dicuci dengan air yang mengalir hingga media agar tidak melekat, selanjutnya dikeringanginkan. Untuk merangsang pembentukan akar maka akar planlet digunting sampai tinggal $2 \mathrm{~cm}$. Plantlet Barangan diaklimatisasi pada media campuran arang sekam dengan pasir steril (2:1). Campuran tersebut dimasukkan kedalam popybag ukuran 12x15 cm. Aplikasi FMA bersamaan waktunya dengan aklimatisasi plantlet. Sumber inokulan FMA yang digunakan adalah dalam bentuk campuran media tanam pasir yang mengandung spora, hifa eksternal dan potongan akar tanaman jagung yang terkolonisasi FMA. Bagian tengah media aklimatisasi (campuran pupuk kandang : arang sekam (1:3)) dari masing-masing polybag ukuran $12 \times 15 \mathrm{~cm}$ dibuat lubang sedalam lebih kurang $5 \mathrm{~cm}$ ditaburkan $50 \mathrm{~g}$ inokulan FMA yang mengandung lebih kurang 100 spora, ditutup dengan selapis tanah $(2 \mathrm{~cm})$ kemudian plantlet ditanam. Pot tersebut diletakkan di atas rak kayu, untuk menjaga agar tetap lembab maka bibit disungkup dengan plastik transparan dengan pencahayaan $60 \%$.

Bibit pisang umur 14 hari dipindahkan ke dalam polybag ukuran $30 \times 40 \mathrm{~cm}$ yang berisi $8 \mathrm{~kg}$ campuran tanah yang terkontaminasi BDB dan pupuk kandang (3:1). Pada saat yang bersamaaan dilakukan pemupukan dengan Urea, NPK dan KCl. Pemupukan dilakukan sekali sebulan dengan $25 \%$ dosis rekomendasi. Untuk 1 ha pisang memerlukan $207 \mathrm{~kg}$ urea, $138 \mathrm{~kg}$ super fosfat dan $608 \mathrm{~kg} \mathrm{KCl}$ (Subakti dan Supriyanto, 1996). Penyiraman bibit dilakukan setiap hari dengan $200 \mathrm{ml}$ air keran. Penyiangan gulma dan pengendalian hama dilakukan secara mekanik.

Pengamatan. Pengamatan dilakukan terhadap masa inkubasi, yang dihitung sejak dilakukannya pemindahan bibit ke polybag yang berisi media tanah yang terkontaminasi bakteri sampai munculnya gejala awal dengan satuan hari setelah pemindahan (hsp). Efektifitas FMA dalam memperlambat masa inkubasi bakteri dihitung menggunakan rumus Sivan \& Chet (1986).

$$
\mathrm{Em}=\frac{\mathrm{MPk}-\mathrm{MPp}}{\mathrm{MPk}} \times 100 \%
$$

dengan:

$\mathrm{Em}=$ Keefektifan FMA,

MPk = Masa inkubasi bakteri pada kontrol (tanpa perlakuan) dan

MPp $=$ Masa inkubasi bakteri pada perlakuan .

Selanjutnya dilakukan penghitungan intensitas serangan penyakit dengan menggunakan skala menurut Baharuddin (1994) yaitu untuk gejala pada daun skala serangannya adalah:

$0=$ tidak ada serangan (tanaman sehat)

$1=1$ helai daun layu/kering

$2=2-3$ daun layu/kering

$3=4-5$ daun layu/kering

$4=>5$ daun layu/kering/tanaman mati

Keefektifan FMA menekan intensitas serangan penyakit darah bakteri dihitung berdasarkan rumus Sivan dan Chet (1986).

Kepadatan populasi BDB pada rhizosfir perakaran tanaman dihitung pada hari ke 15, 30 dan 45 hari setelah pemindahan (hsp) dari $1 \mathrm{~g}$ tanah dengan metode pengenceran seri $\left(10^{6}, 10^{8}, 10^{10}, 10^{12}\right)$ pada medium TZC diinkubasi selama 48 jam.Populasi koloni bakteri dihitung menggunakan rumus Klement et al., (1990):

$$
\mathrm{JB}=\mathrm{A} \times \mathrm{B}
$$

$\mathrm{JB}=$ Jumlah bakteri

$\mathrm{A}=$ Jumlah koloni bakteri

$\mathrm{B}=$ Faktor pengenceran.

Kolonisasi FMA diamati pada potongan akar yang telah diwarnai dengan asam Fuchsin (Sukarno, 1998) dan dihitung dengan rumus Kormanick et al. (1980). 


$$
\text { Kolonisasiakar }=\frac{\text { Jumlah akar terkdonisasi }}{\text { jumlah akar diamati }} \times 100 \%
$$

Data yang diperoleh kemudian dianalisis dengan sidik ragam (ANOVA), apabila terdapat perbedaan yang nyata dilanjutkan dengan uji Duncan New Multiple Range Test (DNMRT) pada taraf 5\% (Gomez dan Gomez, 1995).

\section{HASIL DAN PEMBAHASAN}

Induksi Ketahanan Pisang Barangan terhadap BDB. Semua isolat FMA yang diuji dapat menginduksi ketahanan bibit Barangan terhadap BDB penyebab penyakit darah bakteri. Efek induksi ketahanan tersebut dapat dilihat dari berbagai parameter seperti: tanaman tidak terserang oleh BDB atau jika tanaman bermikoriza tetap juga dapat terserang BDB tetapi terjadi perpanjangan masa inkubasi bakteri di dalam jaringan tanaman, rendahnya persentase dan intensitas serangan penyakit. Di samping itu kepadatan BDB di dalam jaringan akar tanaman pisang Barangan menjadi menurun.

Aplikasi isolat Glomus (Glomus tipe-1 dan G. fasciculatum) berbeda sangat nyata dengan aplikasi Acaulospora tipe-4 untuk parameter masa inkubasi, persentase dan intensitas serangan. Bibit Barangan yang diaplikasi dengan 2 jenis FMA tersebut tidak terserang BDB, aplikasi Acaulospora tipe-4 persentase serangan BDB lebih rendah yaitu $33,33 \%$. Pada tanaman yang tidak diaplikasi FMA (kontrol) semua tanaman terserang BDB. Dengan kata lain aplikasi isolat Glomus (Glomus tipe-1 dan G. fasciculatum) efektif (100\%) menginduksi ketahanan tanaman pisang Barangan diikuti Acaulospora tipe-4 yaitu 66,67\%.

Intensitas serangan BDB pada tanaman dengan aplikasi Acaulospora tipe-4 sebesar 6\% lebih rendah dibanding kontrol $(32,6 \%)$. Efektifitas penekanan intensitas serangan tertinggi ditemukan pada perlakuan aplikasi 2 isolat Glomus yaitu $100 \%$ dan diikuti Acaulospora tipe-4 81,59\%. Rendahnya intensitas serangan pada perlakuan aplikasi FMA indigen berkaitan dengan masa inkubasi dan kepadatan $\mathrm{BDB}$ di rizosfir perakaran tanaman. Masa inkubasi BDB pada tanaman bermikoriza yang terserang BDB menjadi lebih panjang yaitu 30 hst dibanding kontrol (10 hst). Aplikasi Acaulospora tipe-4 efektif memperpanjang masa inkubasi BDB sebesar 20\% dibanding kontrol (Tabel 1). Masa inkubasi BDB berkaitan erat dengan kepadatan BDB di dalam jaringan tanaman. Aplikasi FMA indigen menyebabkan terhambatnya perkembangan BDB dalam jaringan tanaman pisang Barangan.

Kepadatan Populasi BDB. Aplikasi FMA indigen menyebabkan tanaman terinduksi ketahanannya terhadap BDB . Efek induksi tersebut menyebabkan terhambatnya perkembangan BDB di rizosfir tanaman pisang Barangan. Kepadatan populasi BDB ditemukan dalam jumlah rendah di rizosfir perakaran tanaman pisang bermikoriza. Ketiga isolat FMA memiliki kemampuan yang tinggi dalam menekan perkembangan populasi BDB di rizosfir tanaman pisang dengan $\mathrm{R}^{2} \mathrm{e}$ " 0,912 . Isolat $G$. fasciculatum memiliki kemampuan tertinggi dalam menekan perkembangan bakteri dengan persamaan $\mathrm{y}_{\mathrm{Gf}}=-1,354 \mathrm{x}+12,64(\mathrm{R}=0,938)$, diikuti isolat Glomus tipe-1 $\left(\mathrm{y}_{\mathrm{G} 1}=-1,399+12,69\left(\mathrm{R}^{2}=0,932\right)\right.$ dan isolat Acaulospora tipe-4 $\left(\mathrm{y}_{\mathrm{Ac} .4}=-1,097 \mathrm{x}+12,50\left(\mathrm{R}^{2}=\right.\right.$ $0,912)$, sementara pada kontrol $y_{K}=-0,576 x+11,86\left(R^{2}\right.$ $=0,832)$. Kepadatan populasi bakteri mengalami penurunan seiring dengan pertambahan umur tanaman. Kepadatan propagul BDB pada 45 hst lebih rendah dibandingkan pada pengamatan 30 hst dan 15 hst. Kepadatan BDB tertinggi ditemukan pada rizosfer perakaran tanaman tanpa aplikasi FMA indigen (kontrol) (Gambar 1).

Tabel 1. Persentase, intensitas serangan, dan masa inkubasi BDB pada bibit pisang Barangan setelah aplikasi FMA

\begin{tabular}{lrccccc}
\hline \multicolumn{1}{c}{ FMA } & $\begin{array}{c}\text { Serangan } \\
(\%)\end{array}$ & $\begin{array}{c}\text { Efektivitas } \\
(\%)\end{array}$ & $\begin{array}{c}\text { Intensitas } \\
\text { serangan }\end{array}$ & $\begin{array}{c}\text { Efektifitas } \\
(\%)\end{array}$ & $\begin{array}{c}\text { Masa inkubasi } \\
(\mathrm{hst})\end{array}$ & $\begin{array}{c}\text { Efektifitas } \\
(\%)\end{array}$ \\
\hline Glomus tipe 1 & $0,00 \mathrm{a}$ & 100,00 & $0,00 \mathrm{a}$ & 100,00 & $*$ & 100,00 \\
Acaulospora & $33,33 \mathrm{~b}$ & 66,67 & $6,00 \mathrm{~b}$ & 81,59 & 30 & 20,00 \\
tipe 4 & $0,00 \mathrm{a}$ & 100,00 & $0,00 \mathrm{a}$ & 100,00 & $*$ & 100,00 \\
G. fasciculatum & $100,00 \mathrm{c}$ & 0,00 & $32,60 \mathrm{c}$ & 0,00 & 10 & 0,00 \\
Kontrol & &
\end{tabular}

Angka-angka yang diikuti dengan huruf yang sama dalam kolom yang sama tidak berbeda pada taraf uji $5 \%$.

*: tanaman tidak terserang BDB hingga di pindah ke lapangan. 
Beberapa peneliti melaporkan bahwa aplikasi FMA mampu menginduksi ketahanan tanaman melalui penghambatan perkembangan propagul patogen di rizosfir maupun di dalam jaringan tanaman. Aplikasi G.mosseae pada tanaman tomat dapat menginduksi ketahanan tanaman dengan menurunkan kepadatan bakteri yang diukur dari unit pembentuk koloni Erwinia carotovora dan Pseudomonas syringae (Garcia \& Ocampo, 2002). Aplikasi G. fasciculatum pada tanaman tomat di percobaan pot dan pesemaian dapat menurunkan populasi nematoda, massa telur dan indeks puru Meloidogyne incognita. Aplikasi FMA dapat menyebabkan terhambatnya produksi klamidospora Thielaviopsis basicola (Campbell, 1989), tertekannya pertumbuhan Fusarium oxysporum f.sp. lycopersicum pada tanaman tomat (Reflin, 1993). Terhambatnya pembentukan zoosporangium dan pembebasan zoospora
Phytophthora parasitica pada akar jeruk yang bermikoriza (Davis \& Menge, 1980) sehingga dapat menurunkan kerusakan akar (Campbel, 1989).

\section{Kolonisasi FMA Pada Perakaran Tanaman Pisang} Barangan. Aplikasi FMA pada saat aklimatisasi akan lebih cepat mengkolonisasi akar dibandingkan dengan umur yang lebih lanjut. Hifa isolat FMA indigen mampu mempenetrasi akar plantlet pisang Barangan pada saat aklimatisasi dan berkembang secara intensif. Tingkat kolonisasi FMA meningkat seiring dengan pertumbuhan tanaman. Pada pengamatan secara mikroskopis ditemukan perakaran tanaman pisang Barangan terkolonisasi isolat FMA. Hal ini dapat dilihat dari tingginya persentase dan intensitas kolonisasi FMA dalam perakaran tanaman pisang dan kepadatan spora FMA (Tabel 2). Terdapat perbedaan tingkat kolonisasi

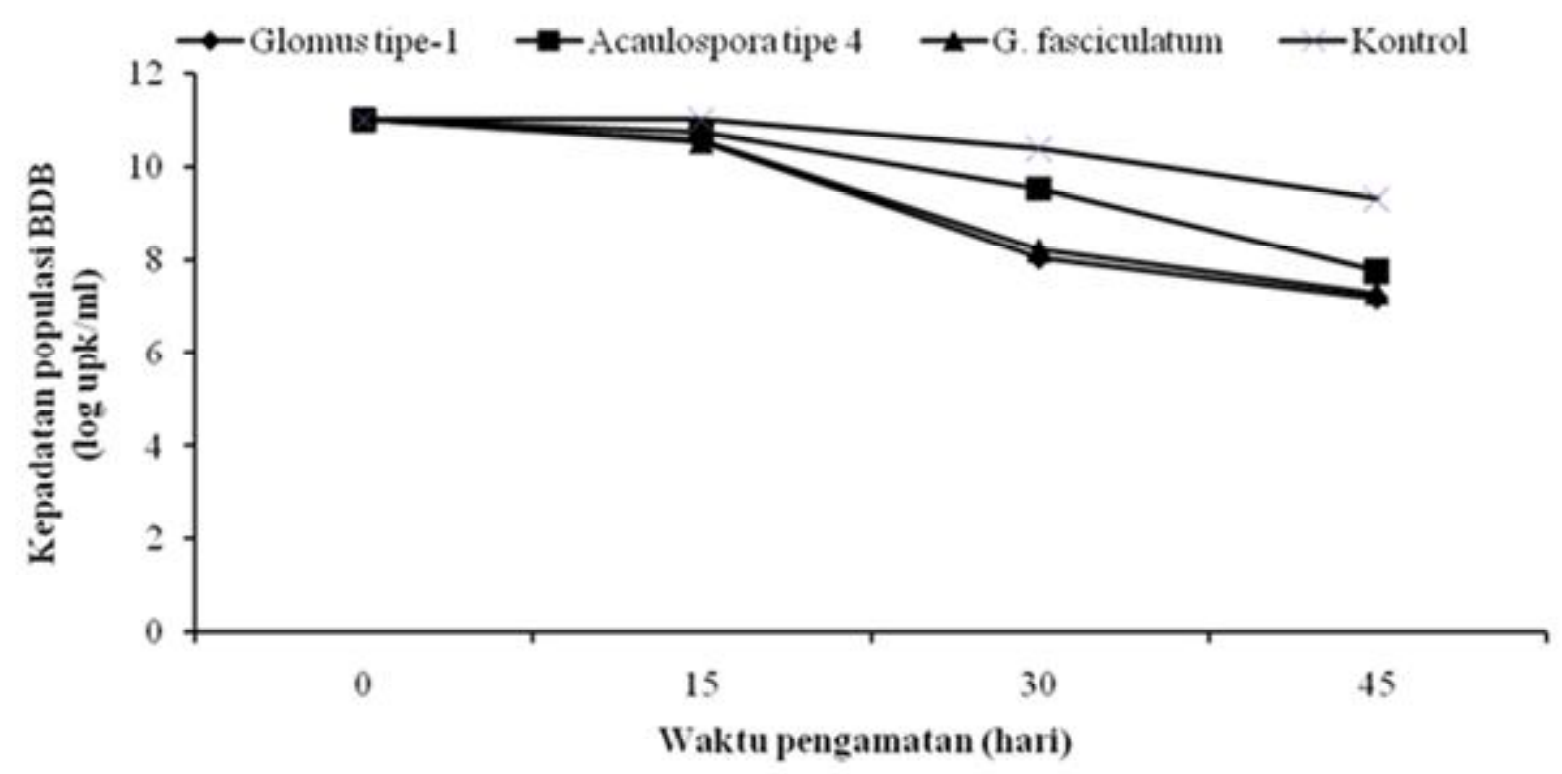

Gambar 1. Kepadatan populasi BDB di rizosfir tanaman pisang Barangan.

Tabel 2. Persentase, intensitas, dan efektifitas kolonisasi dan kepadatan spora FMA pada tanaman pisang Barangan umur 30 hst dan 60 hst

\begin{tabular}{lrrrrrrrc}
\hline & \multicolumn{8}{c}{ Intensitas kolonisasi FMA dan kepadatan spora FMA } \\
\cline { 2 - 9 } Perlakuan & \multicolumn{3}{c}{30 hst } & \multicolumn{4}{c}{60 hst } \\
\cline { 2 - 8 } & PK & ES & IK & KS & PK & ES & IK & KS \\
\hline Glomus tipe-1 & 35 & 85,71 & 2 & 90 & 80 & 91,25 & 4 & 132 \\
Acaulospora tipe- 4 & 25 & 80,00 & 2 & 75 & 80 & 91,25 & 4 & 129 \\
G. fasciculatum & 25 & 80,00 & 2 & 25 & 70 & 90,00 & 4 & 48 \\
Kontrol & 5 & 0,00 & 2 & 5 & 7 & 0,00 & 2 & 12 \\
\hline
\end{tabular}

$\mathrm{PK}=$ persentase kolonisasi, $\mathrm{IK}=$ Intensitas kolonisasi, $\mathrm{KS}=$ Kepadatan spora per $10 \mathrm{~g}$; ES=Efektifitas simbiosis. 
ketiga jenis isolat FMA. Pada 30 hst tampak persentase kolonisasi masih rendah yaitu $25-35 \%$ dengan intensitas kolonisasi 2, mengalami peningkatan seiring dengan bertambahnya umur tanaman. Pada 60 hst persentase kolonisasi telah mencapai $80 \%$ (Glomus tipe-1 dan Acaulospora tipe-4) dan 70\% oleh isolat Glomus fasciculatum dengan intensitas kolonisasi 4. Kepadatan spora FMA juga mengalami peningkatan dengan pertambahan umur tanaman. Kepadatan spora tertinggi ditemukan pada perakaran tanaman pisang yang dikolonisasi oleh Glomus tipe-1 yaitu 132 spora/10 g tanah, diikuti Acaulospora tipe-4 sebanyak 129 spora/ $10 \mathrm{~g}$ tanah dan G.fasciculatum 48 spora/10 g sementara pada kontrol 12 spora/10 g tanah.

Pada pengamatan mikroskopis ditemukan perkembangan FMA di jaringan korteks akar tanaman pisang Barangan. Jaringan ini dikolonisasi oleh hifa internal juga ditemukan struktur arbuskular, spora intraradikal, vesikula dan ekstra hifa matrikal (Gambar 2).Secara mikroskopis teramati bahwa genus Glomus memiliki kemampuan kolonisasi yang tergolong tinggi pada tanaman pisang Barangan. Hal ini didukung oleh kenyataan dilapangan bahwa pada umumnya genus Glomus dapat mengkolonisasi berbagai jenis pisang. Menurut Mosse (1981), genus Glomus memiliki distribusi, rentang tumbuh dan kisaran tanaman inang yang paling luas diantara genus lainnya. Dominasi genus Glomus juga ditemukan pada tanaman pisang Raja Nangka (Musa sp.) di Kabupaten Merangin, Propinsi Jambi dan tanaman kentang di Alahan panjang, Kabupaten Solok, Sumatera Barat (Yelianti, 2005).
Pada tingkat kolonisasi tinggi ditemukan selaput hifa eksternal yang mengkolonisasi permukaan ekternal akar tanaman pisang Barangan. Adanya selaput tipis pada permukaan akar menyebabkan akar sulit dipenetrasi oleh patogen. Brundrett (1994), melaporkan bahwa struktur FMA dapat berfungsi sebagai pelindung biologi terhadap patogen akar karena (1) Terdapatnya selaput tipis hifa sebagai penghalang masuknya patogen, (2) Mikoriza menggunakan hampir semua kelebihan karbohidrat dan eksudat lainnya sehingga tercipta lingkungan tidak sesuai untuk patogen, (3) FMA dapat mengeluarkan antibiotik yang dapat mematikan atau menghambat pertumbuhan patogen. Menurut Berta et al. (1993) kolonisasi FMA menyebabkan perubahan struktur akar dari inang. Perakaran poplar yang diaplikasi G.mosseae menunjukkan terjadinya perubahan morfologi dan arsitektur dan peningkatan frekuensi akar lateral (Hocker et al., 1992). Hasil penelitian Swasono et al. (2006), aplikasi FMA indigenus bawang merah dari daerah pantai mampu memperbaiki kondisi perakaran tanaman. Panjang akar dan berat akar meningkat 47,83\% dan 47,57\% dibanding kontrol (tanpa FMA). Peningkatan jumlah akar, terutama akar adventif juga ditemukan pada tanaman bawang daun (Allium porrum), Platanus acerifolia dan Vitis vinifera yang dikolonisasi Glomus sp (Berta et al., 1990; Schellenbaum et al., 1991; Tisserant et al., 1992). Perubahan tersebut menyebabkan terhalangnya kolonisasi patogen pada akar tanaman yang bermikoriza (Kobayashi \& Branch, 1991).
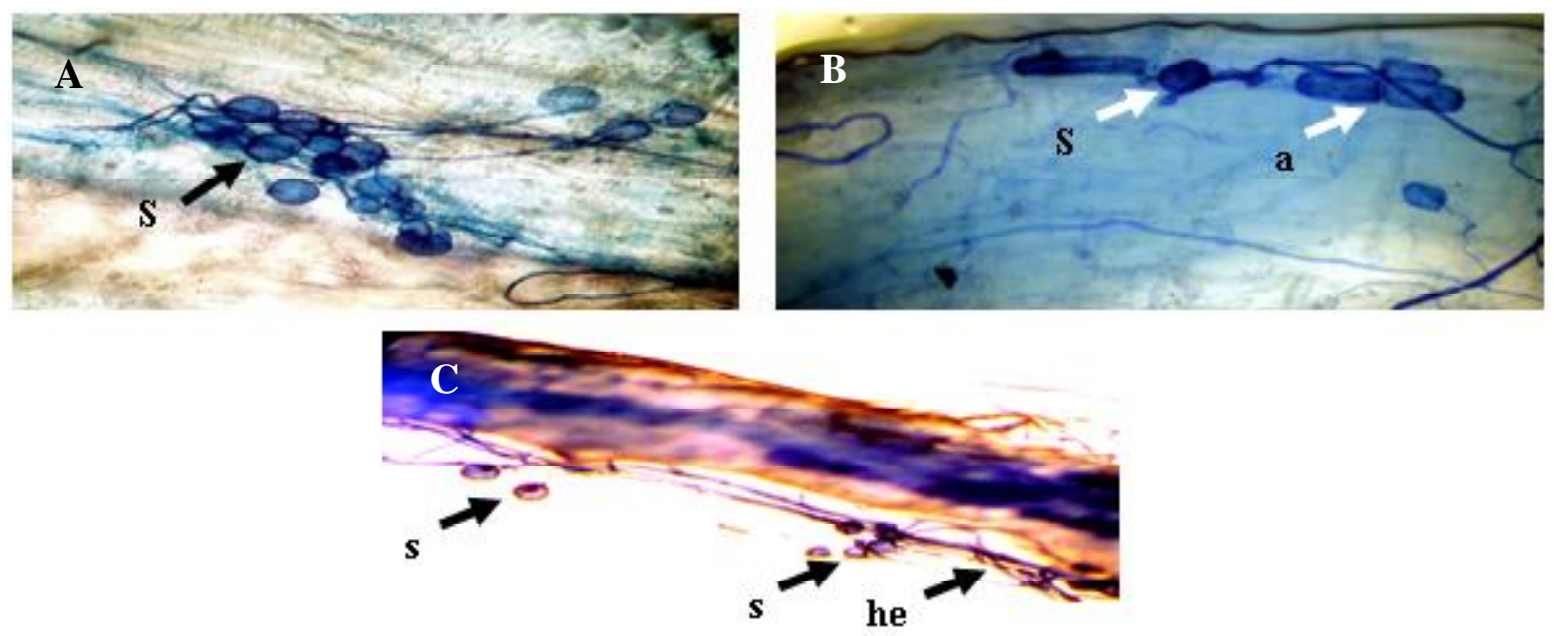

Gambar 2. Struktur kolonisasi FMA pada korteks akar bibit pisang Barangan. (A) Stuktur Glomus tipe-1, (B) Struktur kolonisasi Acaulospora tipe-4. a = arbuskular, he=hifa eksternal, $\mathrm{s}(\mathrm{S})=$ spora , perbesaran $100 x$. 
Perbedaan keefektifan isolat FMA sangat dipengaruhi oleh jenis FMA yang diberikan, umur tanaman pada saat aplikasi FMA, jenis tanaman dan faktor lingkungan lain yang mendukung. Aplikasi FMA pada saat aklimatisasi akan lebih cepat mengkolonisasi akar dibandingkan dengan umur yang lebih lanjut.Selain itu perbedaan keefektifan tersebut disebabkan karena adanya perbedaan kemampuan dari masing-masing isolat dalam bersimbiosis dengan akar bibit pisang. Ada kemungkinan setiap isolat mempunyai preferensi yang berbeda terhadap eksudat yang dikeluarkan oleh bibit pisang tersebut. Menurut Singh et al. (2000); AzcónAguilar et al. (2002); Xavier \& Boyetchko (2004), keberhasilan aplikasi FMA dalam penekanan penyakit akan ditentukan berbagai faktor diantaranya oleh jenis FMA, tingkat kolonisasi FMA, urutan aplikasi, fase pertumbuhan tanaman dan jenis tanaman inang .

\section{SIMPULAN}

Dari kegiatan penelitian dapat disimpulkan bahwa aplikasi FMA (Glomus tipe-1, Acaulospora tipe-4, Glomus fasciculatum) dapat menginduksi ketahanan tanaman pisang Barangan terhadap BDB. Tanaman pisang dengan aplikasi kedua isolat tersebut tidak terserang oleh BDB sementara aplikasi Acaulospora tipe-4 tanaman masih terserang bakteri tetapi persentase, intensitas serangan lebih rendah dan masa inkubasi lebih panjang dibanding kontrol. Kepadatan propagul BDB ditemukan dalam jumlah rendah dalam perakaran tanaman pisang yang dikolonisasi FMA indigen. Peningkatan ketahanan pisang terhadap BDB berkaitan erat dengan tingginya persentase dan intensitas kolonisasi FMA serta intensifnya struktur mikoriza (kepadatan spora, hifa eksternal dan hifa internal) pada perakaran tanaman pisang Barangan.

\section{SANWACANA}

Pada kesempatan ini penulis mengucapkan terima kasih kepada Direktur DP2M Dikti yang telah memberikan dana penelitian Desentralisasi skim Hibah Bersaing melalui DIPA Kopertis Wilayah-I tahun 2012, dan sesuai dengan Surat Perjanjian Penugasan Dalam Rangka Pelaksanaan Program Desentralisasi Penelitian Hibah Bersaing Nomor: 31/K1.1.2/KU.2/2012, tanggal 12 Maret 2012. Kepada Prof.Dr.Ir.Eti Farda Husin.MS atas pemberian isolat Glomus fasciculatum.

\section{DAFTAR PUSTAKA}

Ariningsih S. 2009. Penggunaan Beberapa Isolat Fungi Mikoriza Arbuskula (FMA) dalam Meningkatkan Ketahanan Bibit Pisang Kultivar Kepok terhadap Serangan Penyakit Darah (Blood Disease Bacterium). Skripsi Sarjana Biologi Universitas Andalas. Padang.

Azcón-Aguilar C, Jaizme-Vega MC, \& Calvet C, 2002. The contribution of arbuscular in : Schuepp S, Haselwandter H, Barea JM, Birkhauser Verlag, Basel (eds.) Agriculture: From Genes to Bioproducts, Gianinazzi, Switzerland, pp. 187197.

Baharuddin B. 1994. Pathological, Biochemical and Serological Characterization of the Blood Disease Bacterium Affecting Banana and Plantain (Musa spp.) in Indonesia. Cuvillier Verlag Gottingen.

Berta G, Fusconi A, Trotta A, \& Scannerini S. 1990. Morphogenetic modifications induced by the mycorrhizal fungus Glomus strain E3 in the root system of Allium porrum L. New Phytopathol.114:207-215.

Berta G, Fusconi A, \& Trotta A. 1993. VA Mycorrhizal infection and the morphology and function of root systems. Environ. Exp.Bot. 33:159-173.

Buddenhagen ZW \& Elasser TA. 1962. An Insect spread wild epiphytotic of bluggoe bananas. Nature. 194: 146-165

Brundrett M, Abbot LK, Jasper DA, \& Aswath N. 1994. Mycorrhizal Association in Disturbed and Natural Habitats in Tropical Australia Mycorrhizas for Plantation Forestry in Asia. Proceeding of International Symposium and workshop, Kaping, Guandong Province, P.R. China 7-11 November 1994. Editors M. Brundrett, B.dell. Maljczuk and Gong Mingqin.

Campbell R. 1989. Effect of Glomus intraradices on infection by Fusarium oxysporum f.sp.radicis lycopersici in tomatoes 12 week period. Can. J. Bot. 64:552-556.

Davis RM \& Menge JA. 1980. Influence of Glomus fasiculatus and soil phosphorus on Phytophthora root rot if citrus. Phytopathol. 70:447-452. 
Declerck S, Plenchette C, \& Strullu DG. 1995. Mycorrhizal dependency of banana (Musa acuminata, AAA Group) cultivar. Plant and Soil 176:183-187

Declerk S, Rufyikiri G, Dufey JE, \& Delvaux B. 2000. Arbuscular mycorrhizal fungi might alleviate aluminium toxicity in banana plants. New Phytopatol. 148 (2):343-352.

Eden-Green SJ. 1992. Characteristic of Pseudomonas solanacearum and Related Bacteria from Banana and Plantain in South East Asia in: Lemattre M, Freigoun S, Rudolph K, \& Swings JG. (eds.). Plant Pathogenic Bacteria. INRA.

Garcia-Garrido JM \& Ocampo, JA. 2002. Regulation of the plant defence response in arbuscular mycorrhizal symbiosis. J.exp. Bot. 53:1377-1386.

Gomez KA \& Gomez AA. 1995. Prosedur Statistik untuk Pertanian Edisi Kedua. Penerbit Universitas Indonesia. Jakarta.

Habazar T. 2004. Aspek imunisasi dalam pengendalian penyakit tanaman secara hayati. Orasi ilmiah pada rapat senat terbuka Fakultas Pertanian. Universitas Andalas dalam rangka Dies Natalis ke-47. Tanggal 30 November.

Hooker JE, Munro M, \& Atkinson D. 1992. Vesiculararbuscular mycorrhizal fungi induced alteration in poplar root system morphology. Plant Soil 145:207-214.

Klement Z, Rudolph K, \& Sand DC. 1990. Method in Phytobacteriology. Academia Kiado. Budapest.

Kobayashi N \& Branch K. 1991. Biological control of soil borne disease with vesicular arbuscular mycorrhiza fungi and charcoal compost. In: Proceeding of the international seminar biological control of plant disease and Virus vector. Sept 17-21, Tsukuba. Japan. 153-160.

Kormanick PP, Bryan WC, \& Schultz RC. 1980. Procedures and equipment for staining large number of plant roots for Endomycorrhizal assay. Can. J. Microbiol. 26:536-538.

Maharadingga. 2009. Efektivitas Beberapa Isolat Fungi Mikoriza Arbuskula (FMA) dalam Menekan Perkembangan Penyakit Layu Fusarium pada Bibit Pisang Kultivar Kepok. Skripsi Sarjana Biologi Universitas Andalas. Padang.
Mosse B. 1981. Vesicular-Arbuscular Mycorrhiza Research for Tropical Agriculture. Hawaii Institute of Tropical Agriculture and Human resources, Univ. of Hawaii.

Ploetz RC.1990. Population biology of Fusarium oxysporum $\mathrm{f} \mathrm{sp}$. cubense.pp 63-76 in: Ploetz RC (eds.) Fusarium Wilt of Banana. American Phytopathological Society, St Paul, Minnesota, USA.

Reflin, 1993. Pengaruh inokulasi jamur MVA dan Fusarium oxysporum f. sp lycopersici terhadap infeksi jamur MVA. Perkembangan penyakit layu fusarium dan pertumbuhan tanaman tomat. Tesis Program Pascasarjana Universitas Gajah Mada. Yogyakarta.

Schellenbaum L, Berta G, Ravolanirina F, Tisserant B, Gianinazzi S, \& Fitter AH. 1991. Influence of endomycorrhizal infection on root morphology in a micropropagated woody plant species (Vitis vinifera L.). Ann. Bot. 68:135-141.

Singh R, Adholeya A, \& Mukerji KG. 2000. Mycorrhiza in control of soil borne pathogens. In: Mukerji KG, Chamola BP, \& Snigh J. (eds.) Mycorrhizal biology. Kluwer Academic, New York, pp 173196.

Sivan A\& Chet I. 1986. Biological control of Fusarium spp. in cotton, wheat and muskmelon by Trichoderma harzianum. J. Phytopathol. 116:39-47.

Subakti H \& Supriyanto B. 1996. Perbaikan tehnik budidaya pisang. Balitbangtan. Balai Penelitian Tanaman Buah. Solok

Suharti N, Habazar T, \& Nasir N. 2012. Inokulasi Fungi Mikoriza Arbuskula (FMA) Indigenus pada Bibit Jahe untuk Pengendalian Penyakit Layu Ralstonia solanacearum ras 4. J. Natur Indones. 14(1):61-67.

Sukarno N. 1998. Pewarnaan Akar untuk Pengamatan Koloni Cendawan Mikoriza Arbuskula (FMA) di dalam: Makalah Workshop Mikoriza "Aplikasi Cendawan Mikoriza Pada Tanaman Pertanian, Perkebunan dan Kehutanan”. 5-10 Oktober 1998

Sulyo Y. 1992. Major banana disease and their control. IARD Journal 14 (3 dan 4): 55-62. 
Suswati, Habazar T, Rivai F, \& Putra DP. 2007. Peningkatan Ketahanan Tanaman Bawang Merah (Allium ascalonicum L.) dengan Cendawan Mikoriza Arbuskular terhadap Penyakit Hawar Daun (Xanthomonas axonopodis pv allii). Kongres Asosiasi Mikoriza Indonesia II. Institut Pertanian Bogor 17-21 Juli 2007.

Suswati, Habazar T, Nasir N, \& Putra DP. 2011a. Peningkatan aktifitas enzim poliphenoloksidase (PPO) tanaman pisang dengan introduksi FMAPU10 terhadap penyakit darah bakteri (Ralstonia solanacearum Phylotipe IV). J. Natur Indones. 13(3) Edisi Juni

Suswati, Habazar T, Nasir N, \& Putra DP. 2011b. Respon Fisiologis Tanaman Pisang dengan Introduksi Fungi Mikoriza Arbuskular Indigenus terhadap Penyakit Darah Bakteri (Ralstonia solanacearum Phylotipe IV). Disertasi. Program Pascasarjana. Universitas Andalas. Padang.

Tisserant B, Schellenbaum L, Gianinazzi-Pearson V, Gianinazzi S, \& Berta G. 1992. Influence of infection by an endomycorrhizal fungus on root development and architecture in Platanus acerifolia. Allionia 30:171-181.
Wardlaw CW. 1972. Banana disease. Including plantains and Abaca. Longman.

Xavier L \& Boyetchko S. 2004. Arbuscular mycorrhizal fungi in plant disease control. In: Arora D, Bridge P, Bhatnagar D. (eds.) Fungal Biotechnology in Agricultural, Food, and Environmental Applications. Marcel Dekker, Inc., New York

Yelianti U. 2005. Isolasi Cendawan Mikoriza (CMA) dari Rhizosfer Tanaman Kentang Dan Potensinya Sebagai Pupuk Hayati. Prosiding Seminar nasional Dan Workshop Asosiasi Mikoriza Indonesia (AMI). Dies Natalis Universitas Jambi ke-42, tanggal 9-10 Mei 2005 di Jambi.

Yefriwati, Habazar T, Reflin, \& Muas I. 2005. Aplikasi beberapa Cendawan Mikoriza arbuskular Dalam Meningkatkan Ketahanan Bibit Pisang terhadap serangan Penyakit Layu Bakteri (Ralstonia solanacearum ras 2). Posiding Seminar Nasional dan Workshop Asosiasi Mikoriza Indonesia. Dies Natalis Universitas Jambi ke42, tanggal 9-10 Mei 2005 di Jambi 